\title{
NOTES
}

\section{CONFLICT OF LAWS: LOCAL LAW APPLIED TO SHAREHOLDERS' RIGHTS IN FOREIGN CORPORATION}

$T_{\text {He California corporate securities law contains a provision, rare in }}$ the field of state Blue Sky legislation, that the "sale" of a security includes any change in its rights and privileges ${ }^{1}$ and that the Corporations Commissioner is authorized to refuse a permit for a "sale" unless, in his opinion, the proposed change is fair and equitable to all security holders concerned. $^{2}$

The question whether California could apply these provisions to a foreign corporation was presented in the recent case of Western Airlines v. Sobieski. ${ }^{3}$ A minority group of stockholders exercised their charter right of cumulative voting in a Delaware corporation which had its principal place of business, as well as most of its assets and thirty per cent of its stockholders, in California. Management then attempted to amend the charter to eliminate the cumulative voting provisions. California requires its domestic corporations to have cumulative voting, ${ }^{4}$ but Delaware does not. ${ }^{5}$ The California Corporations Commissioner took the position that the proposed amendment was a "sale," that it was unfair $^{6}$ to a large number of California security holders, and that on

${ }^{2}$ CAL. CORP. CODE $\$ 25009$.

${ }^{2}$ CAL. CORP. CODE $\S 25510$. These provisions are directed toward preventing oppression of shareholders' rights after the corporation has been formed, in contrast to the more traditional concern only with fair disclosure on the original sale. See Orschel, Administrative Protection for Shareholders in California Recapitalizations, 4 StAN. L. Rẹ. 215,218 (1952); Note, Protection for Shareholder Interests in Recapitalizations of Publicly Held Corporations, 58 CoLUM. L. REV. 1030, 1048 (1958). The only similar statute allows a preferred shareholder to seek equitable relief against unfair changes in priority rights, the burden of showing fairness being placed on the proponents of the amendments. NEB. GEN. CORP. LAW ch. 2I, § II62 (I951).

I2 Cal. Rptr. 7I9 (I96I). 'CAL. CORP. CODE $\$ 2235$.

${ }^{8}$ DeL. CODE ANN. tit. 8, \& 214 (1953). The Delaware statute merely permits a corporation to have cumulative voting. The various state statutes are collected in Note, I0\& U. of PA. L. REv. 754, 755 (1960).

- Fairness has been argued to hinge on the necessity for making a change in the corporate structure and the measure of compensation which shareholders will receive for rights surrendered. Latty, Fairness-the Focal Point in Preferred Stock Arrearage Elimination, 29 VA. L. REv. I, 2 (1942). Although well-reasoned arguments have been made both for and against cumulative voting, compare Sobieski, In Support of Cumulative Voting, I5 Bus. LAW. 316 (1960) with Sturdy, Mandatory Cumulative Voting: An Anachronism, I6 BUS. LAW. 550 (1961), its summary elimination after a stockholder fight has developed can hardly be described as either fair or justified by the management's desire to be unhampered by minority shareholder representation on the board of directors. 
this issue the fiction of the plaintiff's Delaware residence should yield to the totality of California contacts so as to require his approval as a condition to eliminating the right of cumulative voting by the shareholders. In an action by the corporation against the Commissioner the trial court held that because the amendment of the articles of incorporation was an "internal affair" between the foreign corporation and its shareholders, the Commissioner had exceeded his jurisdiction. The District Court of Appeal reversed, however, reasoning that a state could regulate such a change to protect its residents. Although the corporation emphatically contended that the California legislature had repealed a provision requiring foreign corporations to have cumulative voting, the court held that the legislature had granted the Commissioner the power to appraise the fairness of changes in the corporate structures of foreign as well as domestic corporations. Finally, the court concluded that the Commissioner's action was not unconstitutional because the foreign corporation did a substantial amount of business within California.

Western'Airlines focuses attention on the familiar corporate practice of incorporating in states with less stringent laws and then operating the entire business in one or more states that could be a continent away, as in the instant case. Such corporations have come to be known as pseudo-foreign or migratory corporations. ${ }^{7}$ A large body of law has grown up involving shareholder suits against foreign corporations, ${ }^{8}$ and it was these analogous precedents on which the trial court in Western Airlines relied. The general rule has been said to be that courts will not take jurisdiction of a suit involving the internal affairs of a foreign corporation, nor, in the exercise of visitorial powers, interfere with the management of a foreign corporation. ${ }^{9}$ Unfortunately, however, this rule has been applied broadly to both pseudo-foreign and

\footnotetext{
${ }^{7}$ See Latty, Pseudo-Foreign Corporations, 65 YALE L.J. 137 (1955).

${ }^{8}$ See generally i7 Fletcher, Corporations $\$ \S 8425-8445.1$ (rev. ed. 1960).

'Id. at $\$ 8425$; Annot., 8 A.L.R.2d 1185 (1949). A leading case defining an "internal affair" is North State Copper and Gold Mining Co. v. Field, 64 Md. 15 x, 20 Atl. 1039 (1885).

The usual function of the internal affairs rule in shareholder suits is to relegate the dissident shareholder to the state of incorporation to assert his rights. The possibility of harsh results has led many courts to the obviously contrived conclusion that a particular controversy did not involve an internal affair. Compare Andrews v. Mines Corp., 205 Mass. 121, 91 N.E. 122 (1910) with In re Rappleye, 43 App. Div. 84,59 N.Y.S. $33^{8}(\times 899)$. Few courts have articulated their underlying thinking in terms of convenience and public policy. The best solution to the problem seems to lie in legislation such as N.C. GEN. STAT. $§ 55-133(a)$ (1960), which states that an action shall not be dismissed solely on the ground that it involves the internal affairs
} 
true foreign corporations alike, with little consideration of whether a decree rendered by the court could actually be enforced. ${ }^{10}$ Early decisions asserted that the suits could not be entertained because of a lack of jurisdiction, ${ }^{11}$ but later cases considered the question a matter of discretion only. ${ }^{12}$ In suits brought by shareholders, most courts now would view the rule as merely one of forum non conveniens. ${ }^{13}$

If the foreign state takes jurisdiction of "internal affairs" litigation, the traditional conflict-of-laws rule requires that the law of the incorporating state be applied to the controversy. ${ }^{14}$ Delaware is the only jurisdiction whose courts have clearly upheld a charter amendment eliminating cumulative voting, ${ }^{15}$ although the statutory language in many other states seems at least equally permissive. ${ }^{16}$ If the California Corporations Commissioner in asserting jurisdiction to challenge the proposed amendment in Western Airlines had measured its legality by Delaware law, the elimination of cumulative voting would have been valid. This result would have frustrated a clear legislative mandate to the Commissioner to measure all changes by their "fairness." However, the Commissioner interpreted the "fairness" test to mean that on this issue he could apply California law to the Delaware corporation to

of a foreign corporation. Dismissal is permitted only when more adequate relief can be had elsewhere, or when the convenience of the parties so requires.

${ }^{10}$ Compare Kelly v. Thomas, $234 \mathrm{~Pa}, 419,83$ Atl. 307 (1912) (large amount of corporate assets within jurisdiction is sufficient guarantee of effectiveness of decree) with Sprague v. Universal Voting Machine Co., I34 Ill. App. 379 (1907) (jurisdiction denied).

${ }^{11}$ See, e.g. Howell v. Chicago \& N.W. Ry., 51 Barb. (N.Y.) 378 (1868). The internal affairs rule is also justified on two other grounds: ( 1 ) the inadvisability of interpreting the law of the domiciliary state. Hogue v. American Steel Foundries, 247 Pa. I2, 92 Atl. 1073 (1915); (2) the desirability of avoiding a possible conflict of decisions. Sauerbrunn v. Hartford Life Ins, Co., 220 N.Y. 363, II5 N.E. 1001 (I917); cf. Guilford v. Western Union Tel. Co., 59 Minn. 332, 61 N.W. 324 ( 1894 ) (possible conflict merely "one of the necessary imperfections in the administration of justice").

${ }^{19}$ Rogers v. Guaranty Trust Co., 288 U.S. 123 (1933); see cases in Note, I 8 Minn. L. REv, I 92, r 95 at n.17 (r933).

${ }^{13}$ Koster v. Lumbermens Mut. Cas. Co., 330 U.S. 518 (1947); Note, Forum Non Conveniens as a Substitute for the Internal Affairs Rule, 58 CoLUM. L. REv, 234 (1958).

14 Restatement, Conflicts \$ 197 (1934).

${ }^{16}$ Maddock v. Vorclone Corp., I 7 Del. Ch. 39, 147 Atl. 255 (1929); of. Quilliam v. Hebronville Utilities Inc., 24 I S.W.2d 225 (Tex. Civ. App. 195I) (change partly justified under "business judgment" rule). Other states have not allowed such an amendment. Wright v. Central Cal. Colony Water Co., 67 Cal. 532, 8 Pac. 70 (1885); Tomlin v. Farmers \& Merchants Bank, 52 Mo. App. 430 (1893); Lowenthal v. Rubber Reclaiming Co., 52 N.J. Eq. 440, 28 Atl. 454 (1894).

${ }^{20}$ See, e.g., N.J. STAT. ANN. § $14: 11$ (1955). 
protect California shareholders, and this choice of law was upheld by the District Court of Appeal. One scholar argues that there is no constitutional prohibition against courts in conflict-of-laws cases looking as a matter of course to the law of the forum for the governing rule, and then applying local law if there is a particular policy to be served. ${ }^{17}$ There is little doubt of the soundness of Western Airlines under this conflict-of-laws standard, for the subject matter of the controversy was strongly related to the governmental policy of the forum. ${ }^{18}$

Western Airlines certainly does not indicate, however, that all foreign corporations must have cumulative voting in order to sell shares or do business in California. The court made it clear that the Commissioner's power of appraisal was a flexible one, ${ }^{10}$ implying that California neither could nor should exert such veto power over a foreign corporation having little contact with the state. ${ }^{20}$

If a state wishes to undertake a reasonable regulation of changes in the corporate structure, no good reason exists why this policy should be thwarted by an essentially domestic corporation through the simple process of incorporating in another state. Judicial utterances to the effect that corporations are the creature of the incorporating state and the powers granted them by those states are the same elsewhere as at home $^{21}$ have no place.in the modern business world. Most modern courts have had little difficulty recognizing the "pseudo-foreign" corporation in shareholder litigation when strong local considerations were involved. ${ }^{22}$. The New York legislature has gone one step further and

${ }^{17}$ Currie, The Constitution and the Choice of Law: Governmental Interests and the Judicial Function, 26 U. CHI. L. REv. 9 (1958). Prof. Currie vigorously opposes any notion that a court should balance respective state policies. See Hill, Govermmental Interests and the Conflict of Laws $-A$ Reply to Professor Currie, 27 U. OF CHI. L. REv. 463 (1960).

18 "Nothing in the Constitution requires a state to nullify its own protective standards because an enterprise regulated has its headquarters elsewhere." Hoopeston Canning Co. v. Cullen, 318 U.S. 313,320 (1943).

19 12 Cal. Rptr. at 728 .

-. 20 Thus viewed, the decision accords with one scholar's argument that local corporation law should be applied to foreign corporations on a selective basis. "A sharp eye for the predominantly local interests would lead to using the term 'pseudo-foreign corporation' as merely a shorthand expression for summarizing the presence of those local interests pertinent to the specific issue in question." Latty, supra note 7 at 161.

${ }^{21}$ Boyette v. Preston Motors Corp., 206 Ala. 240, 89 So. 746 (1921). Cf. Arkansas-Louisiana Elec. Co.-Op. v. Arkansas Pub. Serv. Comm'n, 2 ro Ark. 84, 194 S.W.2d 673 (1946) (entrance conditional upon acceptance of local law).

${ }^{22}$ See, e.g., Toklan Royalty Corp. v. Tiffany, 193 Okla 120, 141 P.2d 571 (1943) (corporation not "foreign" with respect to stockholder examination of records within the jurisdiction). 
defined a "domiciled foreign corporation" in order to delineate accurately the limits of that state's new corporation law's applicability to foreign corporations. ${ }^{23}$

Western Airlines emphasizes the growing tendency of states to apply their own law to the "internal affairs" of foreign corporations which are more closely identified with that state than with any other. The United States Supreme Court will undoubtedly permit this trend to continue, perhaps beyond the pseudo-foreign situation, just as it has allowed states to proportionately tax interstate corporate revenues, ${ }^{24}$ and subject foreign corporations to local suit if they are "doing business" there. ${ }^{25}$

Reappraisal of supposedly settled doctrines will be essential for the interstate corporation. For instance, the general rule is that legality of dividend payments is to be measured by the law of the domiciliary state. $^{20}$ If a foreign corporation conducts most of its operations in a state other than that of its incorporation, Western Airlines suggests that the dividend law of the latter forum could be applied. ${ }^{27}$ One case has already come to this conchusion. ${ }^{28}$

A more vexing question is posed by a true "interstate" corporation, one, for example, that conducts a third of its business in the state of

\footnotetext{
22 A foreign corporation is domiciled if: (I) at least two-thirds of all its outstanding shares, with or without voting rights, are owned, either beneficially or of record, by residents of New York; or (2) at least two-thirds of all its outstanding shares with voting rights are owned, either beneficially or of record, by residents of New York; or (3) at least two-thirds of its business income or its investment income is allocable to New York for franchise tax purposes under the state tax law. Bus. CORP. LAW $\$ 1317$ (to take effect April I, 1963). Only one other state seems to have considered such a statute. Latty, Powers \& Breckenridge, The Proposed North Carolina Business Corporation Act, 33 N.C.L. REv. 26 (1954), discusses N.C.S. Bill N. 49 , the pseudo-foreign corporation provisions of which were not enacted. The proposed definition of a pseudo-foreign corporation was "a foreign corporation ... which engages in no substantial business activity in the state of its incorporation, and which, by virtue of the place and character of its business and personnel, is inore closely identified with the business life of North Carolina than with that of any other state." 33 N.C.L. REv. at 52.

"Northwestern States Portland Cement Co. v. Minnesota, 358 U.S. 450 (1959).

${ }^{25} \mathrm{McGee}$ v. International Life Ins. Co., 355 U.S. 220 (1957). See Kurland, The Supreme Court, the Due Process Clause and the In Personam Jurisdiction of Stato Courts, 25 U. OF CHI. L. REv. 569 (1958).

se Fletcher, Corporations $\$ 5334$ (rev. ed. 1958).

${ }^{27}$ Accord, Latty, supra note 7 at 140 ; Coleman, Corporate Dividends and the Conflict of Laws, 63 HARv. L. REv. 433 (1950).

${ }^{28}$ International Ticket Scale Corp. v. United States, $x 65$ F.2d 358 (2d Cir. r948) (federal tax case). Cf. Irving Trust Co. v. Maryland Cas. Co., 83 F.2d I68 (2d Cir. 1936) (opinion by L. Hand, J.).
} 
incorporation, State $A$, and has its offices there, but has equal contact with State $B$, a state with more stringent dividend restrictions than the domiciliary state. If the dividend's legality were litigated in State $B$, no valid constitutional objections could be raised to State $B^{\prime}$ 's preference of its own law to that of the domiciliary state. The United States Supreme Court has held that the full faith and credit clause does not require a state, when it has legitimate interests to protect, to subordinate its own law to that of another state. ${ }^{2 \theta}$ That Court has also said that a state could, for the protection of its citizens, regulate to some degree the distribution of dividends by a foreign corporation headquartered elsewhere, at least with respect to money earned in the regulating state. ${ }^{30}$ If Western Airlines is extended to apply to the interstate corporation's "internal affairs," some initial confusion will doubtless result. ${ }^{31}$ However, the benefits to be gained by allowing states to enforce strong local policies for the protection of its citizens clearly outweigh the certainty of application of lax corporation laws.

The broader implications of Western Airlines seem far-reaching. The decision clearly will cause pseudo-foreign corporations to reappraise the merits of foreign incorporation. If the choice-of-law principle implicit in Western Airlines were carried to its logical conclusion, ${ }^{32}$ a state would be able to impose regulatory control whenever a foreign corporation's contacts with that state were sufficient. As a result, states, given comprehensive regulatory control over both domestic and foreign corporations, might further examine the evils long intrinsic in corporate reorganization and recapitalization. But whatever effect Western Airlines may have on regulatory aspects of corporation law, the California court's rejection of the internal affairs rule joins other well-reasoned decisions ${ }^{33}$ and New York legislation in formulating a sensible approach to the problem of which state's law is applicable to pseudo-foreign corporations.

\footnotetext{
${ }^{20}$ Alaska Packers Ass'n v. Industrial Acc. Comm'n, 294 U.S. 532 (1935). See also cases cited in Note, 42 Colum. L. Rev. 689, 691 at n.9 (1942); Currie, supra note 17 at $19-30$.

${ }^{30}$ International Harvester Co. v. Wisconsin Dep't of Taxation, 322 U.S. 435,442 (1944) (dictum). "Even if the prohibited act is done in the home state [of a foreign corporation] it may be so bound up in its results with the business in this state that we cannot view it with indifference." German-American Coffee Co. v. Diehl, 2x6 N.Y. 57,64 , 109 N.E. 875,877 (1915) (dictum by Cardozo, J.).

${ }^{32}$ Coleman, supra note 27 , makes an unconvincing argument against any such extension.

${ }^{32}$ See Currie, note 17 supra at 79-80. But compare Latty, supra note 7 at 141 .

${ }^{38}$ See, e.g. State $e x$ rel. Weede v. Iowa So. Util. Co. of Del., 231 Iowa 784,2 N.W.2d 372 (1942); cases cited in Note, 1960 DUKE L.J. $477,480$.
} 